\title{
Effects of photobiomodulation on wound contraction in rats undergoing doxorubicin extravasation: a histomorphometric analysis
}

Efeitos da fotobiomodulação na contração de feridas em ratos submetidos ao extravasamento de doxorrubicina: análise histomorfométrica

Efectos de la fotobiomodulación en la contracción de heridas en ratones sometidos a la extravasación de doxorrubicina: análisis histomorfométrico

How to cite this article:

Freitas KABS, Rocha NS, Minicucci EM, Silva VFB, Langoni H, Popim RC. Effects of photobiomodulation on wound contraction in rats undergoing doxorubicin extravasation: a histomorphometric analysis. Rev ESC Enferm USP. 2021;55:e20200527. DOI: https://doi.org/10.1590/1980-220X-REEUSP-2020-0527.

Karina Alexandra Batista da Silva Freitas $^{1}$

\section{Noeme Sousa Rocha ${ }^{2}$ \\ Eliana Maria Minicucci ${ }^{1}$ \\ Valéria Flávia Batista da Silva ${ }^{3}$ \\ Hélio Langoni \\ Regina Célia Popim ${ }^{1}$}

${ }^{1}$ Universidade Estadual Paulista Júlio de Mesquita Filho, Faculdade de

Medicina de Botucatu, Departamento de Enfermagem, Botucatu, SP, Brazil

${ }^{2}$ Universidade Estadual Paulista Júlio de Mesquita Filho, Faculdade de

Medicina Veterinária e Zootecnia de

Botucatu, Departamento de Clínica

Veterinária, Botucatu, SP, Brazil.

${ }^{3}$ Universidade Estadual de Mato Grosso do Sul, Unidade Universitária de Mundo Novo, Mundo Novo, MS, Brazil.

\begin{abstract}
Objective: To analyze wound contraction and histomorphometric pattern of lesions in Wistar rats undergoing doxorubicin extravasation. Method: Sixty adult female rats were used, divided into four groups of fifteen animals: Group 1 (Control, without antidote); Group 2 (Hyaluronidase); Group 3 (Photobiomodulation), and Group 4 (Hyaluronidase + Photobiomodulation). Doxorubicin $1 \mathrm{mg}(0.5 \mathrm{ml})$ was applied subcutaneously on the animals' back, inducing the wound. Macroscopic and morphometric evaluation of the lesions was performed every two days for 28 days. On the 30th day, euthanasia was performed and the material was collected for histological evaluation. Results: The animals in the photobiomodulation and photobiomodulation + Hyaluronidase groups presented regeneration tissue with neovascularization and acute inflammation, with improvement in wound healing, which did not occur in the other groups. The contraction rates were better in those treated with photobiomodulation and photobiomodulation + Hyaluronidase, with healing percentages of $76.6 \%$ and $72.1 \%$, respectively. Conclusion: The combination of photobiomodulation $(660 \mathrm{~nm}-1 \mathrm{~J})$ with topical hyaluronidase $(65 \mathrm{UTR})$ proved to be effective in the process of wound healing due to extravasation of doxorubicin, and can be incorporated into the practice of clinical oncology.
\end{abstract}

\section{DESCRIPTORS}

Low-Level Light Therapy; Extravasation of Diagnostic and Therapeutic Materials; Antineoplastic Agents; Rats, Wistar. 


\section{INTRODUCTION}

Anti-cancer chemotherapy (ACT) is considered the most used and promising therapy in the treatment of cancer, being a systemic treatment modality in which antineoplastic agents can be toxic. It is classified, according to its potential for skin injury, as irritant, vesicant, and non-vesicant, and may cause different reactions when extravasated into the skin tissue ${ }^{(1-3)}$. In this regard, protocols shall be studied and implemented to avoid complications from the extravasation of these drugs. Extravasation is characterized as the escape of vesicant chemotherapy drug outside the blood vessel, resulting in great damage to the underlying tissue, causing pain and rapidly leading to necrosis, with an incidence of 0.1 to $7 \%$ in peripheral infusion ${ }^{(1-4)}$.

The anthracyclines doxorubicin (DOX), idarubicin, daunorubicin and epirubicin are classified as DNA-binding vesicant chemotherapeutics, being frequently used in the treatment of hematological neoplasms and solid tumors ${ }^{(4)}$.

DOX extravasation is one of the most feared and serious complications, directly affecting the patient's prognosis, as well as their quality of life. After extravasation, DOX can remain in the tissue for up to 28 days and increase the lesion by 5 centimeters from the incident site. In this respect, it leads to chronic, progressive and increased necrosis, causing the lesion to become deeper, more extensive, and more painful ${ }^{(1,3,5)}$.

However, tissue damage caused by extravasation of DOX or any other chemotherapy drug can be avoided with the use of the appropriate antidote ${ }^{(2)}$. Antidotes are chemical agents that neutralize or lessen the effects of a poison or medication. Although several medications have been indicated to treat extravasation, there are still many controversies regarding their safety and efficacy, as most antidotes are recommended based on empirical information ${ }^{(3)}$.

Hyaluronidase is a widely used antidote for extravasation of chemotherapy drug; however, it is specific for non-DNA-binding vesicants, although it is a potential antidote for anthracyclines ${ }^{(2)}$.

Currently, photobiomodulation (PBM), also called low-intensity laser therapy, is widely used to accelerate the healing process and in several medical applications, providing improvements in the quality of life of patients and accelerating treatments. It is considered an important alternative in the treatment of healing processes, as it has anti-inflammatory, analgesic, and healing actions ${ }^{(6)}$. In addition, it does not cause side effects such as those induced by some drugs (for example, corticoids), thus evidencing a faster improvement in the patient's prognosis ${ }^{(7)}$. Another important factor that deserves to be mentioned is that PBM does not cause harmful effects to tissues and the immune system, being characterized as a therapeutic resource often of first choice ${ }^{(6)}$.

For the application of PBM, some parameters shall be considered, such as wavelength, fluence, energy density, pulse structure, and illumination time applied. The selection of which parameter to use will depend on the specificity of each treatment ${ }^{(8)}$.

Extravasation can cause acute injury that, if not treated early, will harm patients, thus warranting the use of PBM.
Therefore, the aim of this study was to investigate whether there is a difference in wound contraction and in the histological analysis of the lesions among the groups of Wistar rats that were subjected to extravasation of doxorubicin, and treated with $\mathrm{PBM}, \mathrm{PBM}+\mathrm{H}$, compared to the control group.

\section{METHOD}

\section{Type OF Study}

This is an experimental study carried out in 60 adult female rats of the Wistar albino strain of the Rattus Norvegicus species, aged between 3 and 4 months.

\section{Population}

The animals came from the Breeding Facility located at the Institute of Biotechnology of Universidade Estadual Paulista "Júlio de Mesquita Filho"(IBTEC). Soon after, they were kept in the Experimentation Breeding Facility, for an adaptation period of 15 days, and only then subjected to the experiment. Female rats were selected due to their behavioral and aggressiveness differences compared to males, making manipulation easier. The experiment was carried out at the Experimental Laboratory for the Diagnosis of Zoonoses, of the Department of Veterinary Hygiene and Public Health, of the Veterinary Medicine and Animal Science School, UNESP, campus of Botucatu/SP. During the entire period, temperature and ammonia levels were controlled, there was bedding change, as well as ad libitum supply of water and feed. They were clinically examined by a veterinarian at admission to the laboratory and throughout the experiment. After the adaptation period, they were randomly divided into four groups called a) control group (without antidote), b) hyaluronidase group $(\mathrm{H}), \mathrm{c})$ low-intensity laser group (L), and d) low-intensity laser group + hyaluronidase $(\mathrm{L}+\mathrm{H})$. Each group consisted of 15 animals that were kept in rectangular, polypropylene cages placed in ventilated $\mathrm{ALESCO}^{\circledR}$ shelves, with 5 animals each, which were kept at room temperature, with free movement. Importantly, after DOX inoculation, the animals were separated and kept in individual cages.

\section{SAmple Definition}

Considering that there is an occurrence of $50 \%$ of cases of necrosis (control) and assuming that the treatment application reduces this percentage to zero (no necrosis), the minimum size for carrying out the experiment with a margin of error of $5 \%, 95 \%$ compatibility and $90 \%$ power will be 15 animals per group (60 animals for the 4 groups).

\section{Data Collection}

Following general inhalation anesthesia with isoflurane gas and trichotomy of the dorsal region with an electric trichotomizer, $1.0 \mathrm{mg}$ of DOX $(0.5 \mathrm{ml})$ was administered in the subcutaneous tissue located between the scapulae and the end of the ribs, using a 1 -ml graduated syringe with 13 $\mathrm{G} \times 4.5 \mathrm{~mm}$ hypodermic needle.

The veterinarian evaluation found that the animals did not show clinical changes consistent with symptoms of pain, 
with no need for analgesia, nor for inhalation anesthesia during animal handling in the following days.

Measures were taken to ensure environmental enrichment, with the placement of paper rolls in the cages, in an attempt to reduce the stress caused by handling.

This was followed by the application of antidotes according to the groups: control group (with no antidote): no antidote was applied; hyaluronidase group $(\mathrm{H})$ : topical hyaluronidase antidote (65 UTR) was applied 15 minutes after inoculation and daily in the form of an ointment on the entire back of the animal, even in the presence of a lesion. PBM Group: PBM was applied $100 \mathrm{~mW}$, red 1 joule, $660-\mathrm{nm}$ wavelength at the point of inoculation, 10 minutes after doxorubicin administration. On subsequent days, in animals that did not present lesions, PBM was still performed at the point of inoculation. When lesions appeared, in wounds up to $1 \mathrm{~cm}$ in area, the center of the lesion was irradiated; wounds up to $2 \mathrm{~cm}$ in area, radiated north, south, east and west; and those with more than $2 \mathrm{~cm}$ in area, more points were covered. Topical dressings with primary coverage were not performed, with the area of the lesion being left exposed.

In the PBM + hyaluronidase $(\mathrm{PBM}+\mathrm{H})$ group, $\mathrm{PBM}$ was performed, as reported in the PBM group, and immediately after the laser, the hyaluronidase antidote was applied, as described in the $\mathrm{H}$ group.

Wound formation process monitoring was carried out every 48 hours by the researcher who evaluated the animals, for twenty-eight days, with the area corresponding to the lesion being measured with the aid of a digital caliper. Measurements were performed in two directions of the wound, on the longest ( $c=$ craniocaudal) stretch and on the widest $(\mathrm{L}=$ laterolateral) stretch, expressed in millimeters and later converted into centimeters.

Euthanasia was performed on the 30th day with removal of the total wound area, including $2 \mathrm{~mm}$ beyond the interface between healthy tissue and the edge of the wound or scar. Samples from animals that did not show lesions were taken from the DOX inoculation site. After collecting the samples, they were fixed in $10 \%$ buffered formalin for 72 hours, then washed in running water, subjected to $70 \%$ alcohol, and the conventional processing of Hematoxylin \& Eosin performed.

The device used to perform the PBM was the model of the company DMC Ltda-São Carlos SP,THERAPY EC. Power was $1 \mathrm{~J}$ at each point (10 seconds each point), fluence of $24 \mathrm{~J} / \mathrm{cm}^{2}$ in continuous mode. The spacer and transparent film were used on the device for protection.

\section{Data Analysis and Treatment}

The area of the lesion was calculated at each assessment $(\mathrm{A}=\mathrm{L} \times \mathrm{W})$. The area of wound contraction was calculated by subtracting the initial area $\left(\mathrm{A}_{0}\right)$ from the final area (Af) $\left(\mathrm{A}_{0}-\mathrm{Af}\right)$. The Wound Contraction Percentage (WCP) was calculated by subtracting the initial area $\left(A_{0}\right)$ determined on the day the lesion appeared from the wound contraction measurement $(\mathrm{Ac})$, so that $\mathrm{WCP}=\mathrm{A} 0-\mathrm{AC} / \mathrm{A} 0 \times 100^{(9)}$.

To check possible differences among the means of the area of contraction of skin lesions in the different treatments, one-way analysis of variance (ANOVA) was used.
In this analysis, each contraction value corresponded to the dependent variable and the treatments corresponded to the independent variable. The ANOVA assumptions were examined by the Shapiro-Wilk (normality) and Levine (homogeneity) tests and were met. In cases of significant differences among the means, the Tukey test was applied to identify which treatments differed from each other. These analyses were computed using the software Statistica 7.0 (STATSOFT, 2007).

\section{Ethical Aspects}

The research was approved on $02 / 11 / 2019$ by the Animals Research Ethics Committee (CEUA) of the Veterinary Medicine and Animal Science School of Botucatu - UNESP, under protocol 0026/2019.

\section{RESULTS}

Of the 60 animals, there was a loss of 23, with the total sample of 37 animals.

\section{Morphometric Analysis - Wound Contraction}

Skin changes and the beginning of the wound process started on D4, being more evident in group C (7/15:46\%). Maximum wound development occurred on D8; however, some animals in the PBM group (4/15:26\%) did not develop lesions by the end of the study.

It was observed that after 28 days of evaluation, 2 animals in the $\mathrm{PBM}$ and $\mathrm{PBM}+\mathrm{H}$ group presented complete wound healing.

Of the total of animals that completed treatments, $56.0 \%$ had wound contraction. One-factor Anova indicated significant differences among treatments for this attribute $(\mathrm{F}=33.08 ; \mathrm{p}<0.001)$ (Figure 1). Tukey's test revealed that Control $(p=0.047539)$ and laser $(p=0.033896)$ differed significantly from laser + hyaluronidase by the lowest mean values recorded in the area of skin lesion contraction. There was total wound contraction in animals treated with PBM (2 rats) and PBM + hyaluronidase (2 rats).

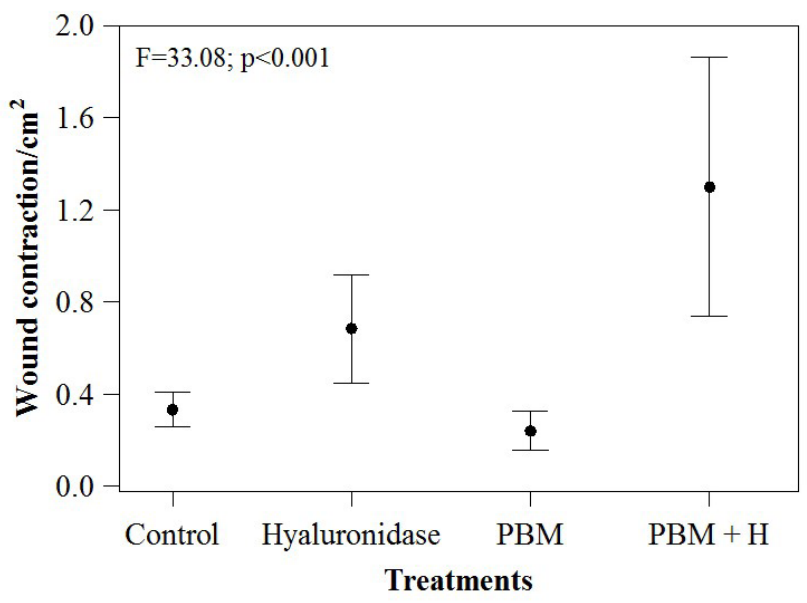

Figure 1 - Mean values of wound contraction area $\left(\mathrm{cm}^{2}\right)$. Means are represented by circles and standard error in bars. $\mathrm{C}=$ Control, $\mathrm{H}=$ Hyaluronidase, $\mathrm{PBM}=$ Photobiomodulation; $\mathrm{PBM}+\mathrm{H}=$ Photobiomodulation + Hyaluronidase. 
Considering WCP, it is observed that there was a gradual increase in the healing process among treatments. The highest mean values of the contraction rate of skin lesions were recorded for animals treated with PBM and PBM + hyaluronidase, representing a healing percentage of $76.6 \%$ and $72.1 \%$ in relation to the initial area, respectively (Figure 2).

The more healed the wounds the more positive the mean values of the contraction rates.

\section{Histological Analysis}

The parameters evaluated histologically - epithelium, necrosis, crust, abscess, regeneration, inflammation (acute or chronic) and inflammation intensity (mild, moderate, intense) - did not show statistically significant differences in the test used among the groups evaluated. However, data considered important in this study were listed.

The presence of crust was more observed in the $\mathrm{PBM}+\mathrm{H}$ group $(3 / 7 ; 42 \%)$ when compared to group C (4/13;30\%) and the PBM group (3/11;37.7\%). There was no evidence of crusted epithelium in the samples from group $\mathrm{H}$.

In general, the most predominant inflammatory intensity was moderate, presented in $40 \%(15 / 37)$ of the animals. No differences were observed among the experimental groups $(\mathrm{p}=0.6563)$.

Groups PBM and PBM+H did not present samples with necrosis, which was more evident in groups $\mathrm{H}(2 / 6 ; 33 \%)$ and $\mathrm{C}(3 / 13 ; 23 \%)$.

As for epithelium regeneration, it was observed that it was more present in the groups with the hyaluronidase antidote, with $\mathrm{PBM}+\mathrm{H}(4 / 7 ; 57 \%)$ (Figure 3), $\mathrm{H}$ (3/6;50\%), demonstrating a more pronounced regeneration than in the groups PBM (5/11;45\%) and group C (4/13;30\%), despite the borderline significance $(\mathrm{p}=0.6803)$.

It was evident that samples from two animals in the PBM group (2/11;18\%) did not show any histological alterations, remaining with intact epithelium.

Table 1 shows the main data found in the samples.

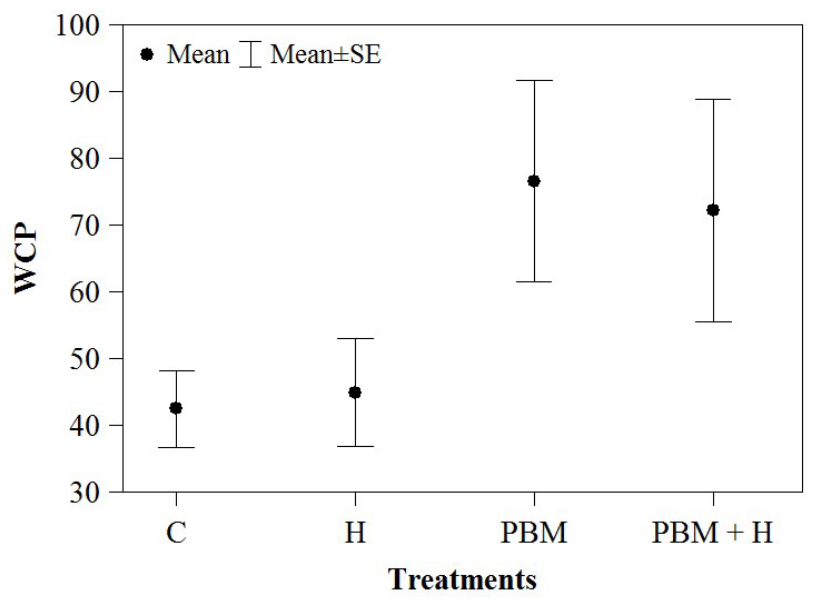

Figure 2 - Wound Contraction Percentage recorded for the different skin lesion treatments. $\mathrm{C}=$ Control, $\mathrm{H}=$ Hyaluronidase, $\mathrm{PBM}=$ Photobiomodulation; $\mathrm{PBM}+\mathrm{H}=$ Photobiomodulation + Hyaluronidase.

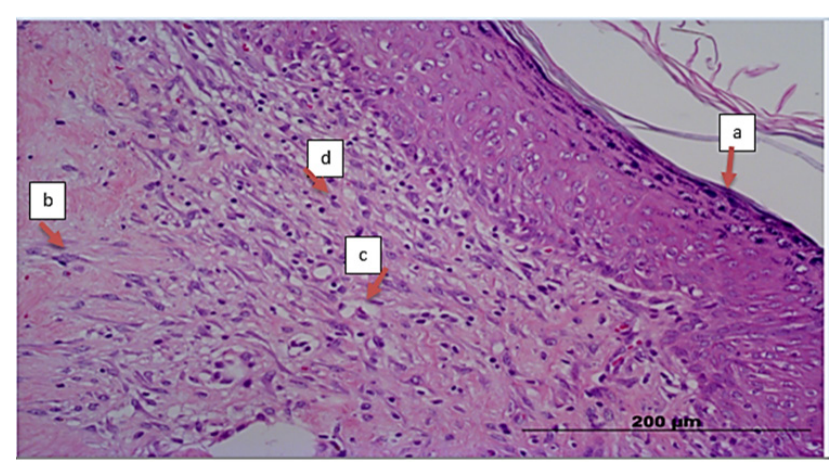

Figure $3-\mathrm{PBM}+\mathrm{H}$ group, treated with photobiomodulation + hyaluronidase. At the end of the experiment on the 30th day, it was observed: (a) regenerated epithelial layer (arrow), (b) superficial and deep dermis, observe an expressive amount of young fibroblasts, neovascularization (c) and mononuclear inflammatory infiltrate $(d)$. HE.

Table 1 - Microscopic description of the groups of samples collected on the 30th day. $\mathrm{C}=$ Control, $\mathrm{H}=$ Hyaluronidase, $\mathrm{PBM}=$ Photobiomodulation; $\quad \mathrm{PBM}+\mathrm{H}=$ Photobiomodulation + Hyaluronidase - Botucatu, SP, Brazil, 2020.

\begin{tabular}{|c|c|c|c|c|}
\hline \multirow{2}{*}{ Microscopic description } & \multicolumn{4}{|c|}{ Groups } \\
\hline & $\mathrm{C}$ & $\mathbf{H}$ & PBM & $\mathrm{PBM}+\mathrm{H}$ \\
\hline $\begin{array}{l}\text { Ulcerated epithelium, superficial to } \\
\text { deep dermis with chronic foreign } \\
\text { body-like inflammation, with giant } \\
\text { cell formation }\end{array}$ & 1 & 0 & 0 & 0 \\
\hline $\begin{array}{l}\text { Epithelium with abscess that extends } \\
\text { to the deep dermis }\end{array}$ & 1 & 0 & 0 & 0 \\
\hline $\begin{array}{l}\text { Epithelium with coagulation } \\
\text { necrosis and acute inflammation to } \\
\text { deep dermis }\end{array}$ & 2 & 0 & 0 & 0 \\
\hline $\begin{array}{l}\text { Epithelium with coagulation } \\
\text { necrosis and chronic inflammation } \\
\text { with giant cells }\end{array}$ & 1 & 0 & 0 & 0 \\
\hline $\begin{array}{l}\text { Epithelium with crust from } \\
\text { superficial to deep dermis, acute } \\
\text { inflammation and presence of } \\
\text { neovascularization }\end{array}$ & 2 & 0 & 0 & 0 \\
\hline $\begin{array}{l}\text { Regeneration with } \\
\text { neovascularization }\end{array}$ & 2 & 0 & 5 & 4 \\
\hline $\begin{array}{l}\text { Crusted epithelium and abscess with } \\
\text { acute inflammation }\end{array}$ & 2 & 0 & 1 & 2 \\
\hline $\begin{array}{l}\text { Regeneration epithelium with } \\
\text { neovascularization }\end{array}$ & 1 & 3 & 0 & 0 \\
\hline $\begin{array}{l}\text { Regeneration epithelium } \\
\text { with acute inflammation and } \\
\text { neovascularization }\end{array}$ & 1 & 0 & 0 & 0 \\
\hline $\begin{array}{l}\text { Epithelium with coagulation } \\
\text { necrosis and acute inflammation to } \\
\text { muscularis }\end{array}$ & 0 & 2 & 0 & 0 \\
\hline $\begin{array}{l}\text { Epithelium with abscess, chronic } \\
\text { inflammation with giant cells }\end{array}$ & 0 & 1 & 1 & 0 \\
\hline Normal epithelium, no lesion & 0 & 0 & 2 & 0 \\
\hline $\begin{array}{l}\text { Epithelium with abscess with } \\
\text { chronic inflammation and giant cells }\end{array}$ & 0 & 0 & 1 & 0 \\
\hline $\begin{array}{l}\text { Epithelium with crust and } \\
\text { abscess and dermis with chronic } \\
\text { inflammation with the presence of } \\
\text { giant cells }\end{array}$ & 0 & 0 & 1 & 0 \\
\hline $\begin{array}{l}\text { Crusted epithelium and dermis with } \\
\text { acute inflammation }\end{array}$ & 0 & 0 & 0 & 1 \\
\hline Total & 13 & 6 & 11 & 7 \\
\hline
\end{tabular}

Source: Research data, 2020. 


\section{DISCUSSION}

We suggest that the loss of animals may be related to several factors, such as toxicities generated by anthracycline, hyaluronidase, and factors related to animal behavior.

The groups that lost the most animals were those using hyaluronidase. Although the groups were evaluated every 2 days, hyaluronidase was administered daily, and this procedure can be considered stressful due to the intense animal handling, despite the paper rolls in the cage to distract the animal. It was observed that hyaluronidase, even being administered in small amounts on the animal's back, flowed to places where licking was easier, such as the laterality of the back, favoring ingestion by the animal.

It should be noted that during DOX extravasation, the DOX - DNA complex is formed, which accounts for cell death, being released and reaching neighboring cells, triggering an uncontrolled process, where cell toxicity is high due to the release of free radicals, causing oxidative stress, increasing the inflammatory process and causing tissue necrosis ${ }^{(10)}$.

The oxidative stress generated by the lesion is directly related to the migration, activation, and accumulation of inflammatory cells (neutrophils and macrophages), causing lipid and cell membrane oxidation, and DNA fragmentation, promoting an imbalance. PBM acts directly on oxidative stress. Red and infrared light is absorbed by cytochrome $\mathrm{C}$ oxidase (present in mitochondria), causing an increase in the production of reactive oxygen species, leading to a restoration of cell balance through the production of antioxidant enzymes ${ }^{(11)}$.

Hyaluronidase is an enzyme and acts on the degradation of hyaluronic acid that is present in the extracellular matrix, promoting diffusion of the extravasated drug. It is recommended for extravasation of taxanes, vinca alkaloids, and etoposide. Commonly, subcutaneous injections of $0.2 \mathrm{ml}$ are used, with concentrations of 100 to 150 IU. The number of injections shall be administered according to the size of the lesion area $^{(12)}$.

In a study carried out using $36 \mathrm{Wistar}$ rats, which received intradermal injection of vincristine and different antidotes (adrenomedullin, adrenomedullin + hyaluronidase, or hyaluronidase), it was observed that the animals belonging to the hyaluronidase group obtained a better preservation of the skin morphology, causing only small changes, significantly reducing the size of the ulcer and the histological signs of tissue damage ${ }^{(13)}$.

However, dexrazoxane is the only Food and Drugs Administration (FDA) and European Commission approved antidote for DOX extravasation with an efficacy of $98 \%$. The mechanism of action is the drug binding to the iron molecule, preventing the formation of free radicals ${ }^{(4)}$. Besides being unfeasible for the public sector (due to the price), it can cause side effects such as nausea, vomiting, mild pain at the infusion site, and reversible increases in liver enzymes ${ }^{(1-2)}$.

We observed that the groups using PBM had better rates of contraction and important histological features such as absence of necrosis, presence of neovascularization, and acute inflammatory reaction. The association of PBM with hyaluronidase favored epithelial regeneration compared to other groups. We suggest that this fact is related to the maintenance of the moist environment, favoring the healing process.

Although there are no published studies on use of PBM for DOX extravasation, its efficiency has already been proven in other types of lesions, and it can be associated with topical therapies ${ }^{(14)}$.

PBM is widely used in wounds of different etiologies, especially burns. A study carried out in diabetic patients with third-degree burns showed that the association of PBM with autologous fibroblast transplantation achieved satisfactory results, and was considered an effective method in the treatment of extensive wounds ${ }^{(15)}$.

In another study, the use of three protocols in the repair of excisional wounds in 60 rats was evaluated and it was observed that PBM provided a significant decrease in the severity of the inflammatory response, regardless of the protocol. The 4J protocol had the highest collagen deposition rates, suggesting that daily application induced a more intense stimulation effect ${ }^{(16)}$.

Histomorphometric analysis in wound healing using different wavelengths $(658,830$, and $904 \mathrm{~nm})$ observed that the wavelength of $658 \mathrm{~nm}$ was more effective in terms of tissue repair ${ }^{(17)}$. In this respect, similar results were found in our study, demonstrating that the selection of wavelength was the correct one, as there was a significant improvement in wound contraction, presence of neovascularization, fibroblasts, and in the acute inflammatory process.

We observed that some animals in the PBM group did not present lesions, demonstrating that PBM is also effective in keeping skin integrity. The use of PBM in the prevention and treatment of oral mucositis in cancer patients treated with chemotherapy and/or radiotherapy of the head and neck, or in a conditioning regimen for hematopoietic stem cell transplantation, is already well-established, and its use is recommended by the Mucositis Study Group of the Multinational Association of Supportive Care in Cancer (MASCC/ISOO) $^{(18)}$

PBM brings a change of paradigm in the treatment of DOX extravasation, due to its important cost-benefit, ease of handling, and the change in the quality of life provided. However, the high mortality related to the ingestion of hyaluronidase is a questionable aspect for the proposition of new studies with the same protocol.

The implementation of evidence-based care allows nurses to apply the best clinical practice, avoiding most extravasation cases. The nurse is responsible for managing extravasation and shall have the competence to do so. The training of the nursing staff and the implementation of prophylactic protocols are critical for the prevention of these events. Carrying out PBM requires qualified and/or trained professionals to use it. The Federal Council of Nursing, in its resolution $567 / 2018^{(19)}$, authorizes the application of the technology by nurses. More in-depth measures of training and scientific development in PBM shall be carried out to promote the empowerment of nurses in this area. 


\section{Study Limitations}

We considered as a limitation in this study the loss of some animals from the groups that used hyaluronidase, which may have occurred due to toxicity.

Another limiting factor is the lack of literature on the use of photobiomodulation in anthracycline extravasation.

\section{Advances in the Area of Nursing/Health}

This research can be considered the starting point for the use of photobiomodulation in the extravasation of anthracycline, ensuring professional autonomy for nurses in the prevention and treatment of this very important adverse event.

New technologies shall be incorporated to ensure better care for cancer patients.

\section{CONCLUSION}

Wound contraction and histomorphometric pattern of lesions in Wistar rats subjected to doxorubicin extravasation demonstrated that the combination of PBM with topical hyaluronidase was effective in the wound healing process. Histological analysis and wound contraction revealed that this therapy was able to stimulate the healing process.

\section{RESUMO}

Objetivo: Analisar a contração de feridas e padrão histomorfométrico das lesões em ratos Wistar submetidos ao extravasamento de doxorrubicina. Método: Utilizados 60 ratos fêmeas adultos, divididos em quatro grupos de quinze animais: Grupo 1 (Controle, sem antídoto); Grupo 2 (Hialuronidase); Grupo 3 (Fotobiomodulação) e Grupo 4 (Hialuronidase + Fotobiomodulação). Aplicado $1 \mathrm{mg}$ $(0,5 \mathrm{ml})$ de doxorrubicina no subcutâneo do dorso dos animais, induzindo a ferida. Realizada avaliação macroscópica e morfométrica das lesões a cada dois dias por 28 dias. No $30^{\circ}$ dia foi realizada a eutanásia e coleta do material para avaliação histológica. Resultados: Os animais dos grupos fotobiomodulação e fotobiomodulação+Hialuronidase apresentaram tecido de regeneração com neovascularização e inflamação aguda, com melhora na cicatrização das feridas, o que não ocorreu nos outros grupos. As taxas de contração foram melhores nos tratados com fotobiomodulação e fotobiomodulação + Hialuronidase, com percentual de cicatrização de 76,6\% e 72,1\%, respectivamente. Conclusão: A combinação da fotobiomodulação (660 nm-1 J) com hialuronidase tópica (65 UTR) mostrou-se eficaz no processo de cicatrização de feridas por extravasamento de doxorrubicina, podendo ser incorporada à pratica da oncologia clínica.

\section{DESCRITORES}

Terapia com Luz de Baixa Intensidade; Extravasamento de Materiais Terapêuticos e Diagnósticos; Antineoplásicos; Ratos Wistar.

\section{RESUMEN}

Objetivo: Analizar la contracción de heridas y patrón histomorfométrico de las lesiones en ratones Wistar sometidos a la extravasación de doxorrubicina. Método: Fueron utilizadas 60 ratas adultas, divididas en cuatro grupos de quince animales: Grupo 1 (Control sin antídoto); Grupo 2 (Hialuronidasa); Grupo 3 (Fotobiomodulación) y Grupo 4 (Hialuronidasa + Fotobiomodulación). Se aplicó $1 \mathrm{mg}$ $(0,5 \mathrm{ml})$ de doxorrubicina en el subcutáneo del dorso de los animales, induciendo la herida. Realizada evaluación macroscópica y morfométrica de las lesiones cada dos días por 28 días. En el $30^{\circ}$ día se realizó la eutanasia y recolección del material para evaluación histológica. Resultados: Los animales de los grupos fotobiomodulación y fotobiomodulación+ Hialuronidasa presentaron tejido de regeneración con neovascularización e inflamación aguda, con mejoría de la cicatrización de las heridas, lo que no ocurrió en otros grupos. Las tasas de contracción fueron mejores en los tratados con fotobiomodulación y fotobiomodulación + Hialuronidasa, con porcentaje de cicatrización de 76,6\% y 72,1\%, respectivamente. Conclusión: la combinación de la fotobiomodulación (660nm-1J) con hialuronidasa tópica (65 UTR) demostró ser más eficaz en el proceso de cicatrización de heridas por extravasación de doxorrubicina, lo que posibilitó adoptarla en la práctica de la oncología clínica.

\section{DESCRIPTORES}

Terapia por Luz de Baja Intensidad; Extravasación de Materiales Terapéuticos y Diagnósticos; Antineoplásicos; Ratas Wistar.

\section{REFERENCES}

1. Melo JMA, Oliveira PP, Souza RS, Fonseca DF, Gontijo TF, Rodrigues AB. Prevention and conduct against the Extravasation of antineoplastic chemotherapy: a scoping review. Rev Bras Enferm [Internet]. 2020 [cited 2020 Nov 08];73(4):e20190008. Available from: https://www. scielo.br/pdf/reben/v73n4/0034-7167-reben-73-04-e20190008.pdf

2. Melo JMA, Oliveira PP, Rodrigues AB, Souza RS, Fonseca DF, Gontijo TF, et al. Bundle construction and assessment before antineoplastic extravasation: a methodological study. Acta Paulista de Enfermagem [Internet]. 2020 [cited 2020 Nov 08];33:eAPE20190075. Available from: https://acta-ape.org/wp-content/uploads/articles_xml/1982-0194-ape-33-eAPE20190075/1982-0194-ape-33-eAPE20190075-en.pdf

3. Boulanger J, Ducharme A, Dufour A, Fortier S, Almanric K. Comité de l'évolution de la pratique des soins pharmaceutiques (CEPSP); Comité de l'évolution des pratiques en oncologie (CEPO). Management of the extravasation of anti-neoplastic agents. Support Care Cancer [Internet]. 2015 [cited 2020 Nov 08];23(5):1459-71. Available from: https://pubmed.ncbi.nlm.nih.gov/25711653/

4. Koleini N, Kardami E. Autophagy and mitophagy in the context of doxorubicin-induced cardiotoxicity. Oncotarget [Internet]. 2017 [cited 2020 Nov 17];8(28):46663-80. Available from: https://www.ncbi.nlm.nih.gov/pmc/articles/PMC5542301/pdf/oncotarget-08-46663.pdf

5. Miura NO, Aung NY, Yamakwa M. Effect of cold and hot compress on neutrophilic migration to the site of doxorubicin extravasation. Int J Clin Exp Pathol [Internet]. 2019 [cited 2020 Nov 08]:12(4):1468-77. Available from: https://www.ncbi.nlm.nih.gov/pmc/articles/ PMC6947076/pdf/ijcep0012-1468.pdf

6. Lima NEP, Gomes GM, Feitosa ANA, Bezerra ALD, Sousa MNA. Laser therapy low intensity in wound care and practice nurses. Revista de Enfermagem da UFPI [Internet]. 2018 [cited 2020 Feb 29];7(1):50-6. Available from: https://revistas.ufpi.br/index.php/reufpi/article/ view/6223/pdf 
7. Gomes CF, Schapochnik A. The therapeutic use of low intensity laser (LLLT) in some diseases and its relation to the performance in speech therapy. Distúrb. Comun. [Internet]. 2017 [cited 2020 Nov 08]; 29(3):570-8. Available from: https://pesquisa.bvsalud.org/portal/resource/ pt/biblio-881883

8. Silva Neto CP, Freire O Jr. A gift from Apollo: lasers, history, applications. Revista Brasileira de Ensino de Física [Internet]. 2017 [cited 2020 Feb 29];39(1):e1502. Available from: https://www.scielo.br/pdf/rbef/v39n1/1806-1117-rbef-39-01-e1502.pdf

9. Falcão SC, Coelho ARB, Almeida EL, Galdino CAPM. Modified processo f image reproduction and amplification for measurement of area by planimetry. Application in plain wounds produced in dogs treated by occlusive skin frog dressing. Braz J Vet Res Anim Sci [Internet]. 2001 [cited 2020 Feb 29];38(4):165-9. Available from: https://www.scielo.br/pdf/bjvras/v38n4/9700.pdf

10. Kesik V, Yuksel R, Yigit N, Saldir M, Karabacak E, Erdem G, et al. Ozone Ameliorates Doxorrubicine - Induced Skin Necrosis - results from an animal model. The International Journal of Lowel Extremity Wounds [Internet]. 2016 [cited 2020 Feb 29];15(3):248-54. Available from: https://journals.sagepub.com/doi/pdf/10.1177/1534734615597863?casa_token=QI6roAUEv2gAAAAA:87pwpy20U6nrFYYE0dkqj3 jxhpxwYnbNuQhqwyinpDtVID_GanBlwcCTQBGi2kOpB48DRpA_MyBgUXw

11. Dos Santos SA, Serra AJ, Stancker TG, Simões MCB, Dos Santos Vieira MA, Leal-Junior EC, et al. Effects of photobiomodulation therapy on oxidative stress in muscle injury animal models: a systematic review. Oxid Med Cell Longev [Internet]. 2017 [cited 2020 Feb 29];2017:5273403. Available from: https://www.hindawi.com/journals/omcl/2017/5273403/

12. Kreidieh FY, Moukadem HA, El Saghir NS. Overview, prevention and management of chemotherapy extravasation. World J Clin Oncol [Internet]. 2016 [cited 2020 Nov 17];7(1):87-97. Available from: https://www.ncbi.nlm.nih.gov/pmc/articles/PMC4734939/pdf/ WJCO-7-87.pdf

13. Kesik V, Kurt B, Tunc T, Karslioglu Y, Citak EC, Kismet E, Koseoglu V. Melatonin ameliorates doxorubicin-induced skin necrosis in rats. Annals of Plastic Surgery [Internet]. 2010 [cited 2020 Feb 29];65(2):250-3. Available from: https://journals.Iww.com/annalsplasticsurgery/ Fulltext/2010/08000/Melatonin_Ameliorates_Doxorubicin_induced_Skin.29.aspx?casa_token=Yp6UqoQ8ucEAAAAA:Bci7fwuxRx-9z1yk YuhXYx3JKFs9pW3RyLBcAT9pAjPOIgl_6HNveCevLmogP5cq_92Ru6rl_tuVwCLM3jZr4xQuC0I3GZg

14. Carvalho AFM, Feitosa MCP, Coelho NPMF, Rebêlo VCN, Castro JG, Sousa PRG, et al. Low-level laser therapy and Calendula officinalis in repairing diabetic foot ulcers. Rev Esc Enferm USP [Internet]. 2016 [cited 2021 Feb 28]:50(4):626-32. Available from: http://www.scielo. br/pdf/reeusp/v50n4/0080-6234-reeusp-50-04-0628.pdf

15. Nilforoushzadeh MA, Kazemikhoo N, Mokmeli S, Zare S, Dahmardehei M, Vaghar Doost R, et al. An open-label study of low-level laser therapy followed by autologous fibroblast transplantation for healing grade 3 burn wounds in diabetic patients. J Lasers Med Sci [Internet] 2019 [cited 2020 Feb 29];10 (Suppl 1):S7-12. Available from: https://journals.sbmu.ac.ir/jlms/article/view/17356/pdf

16. Cunha JLS, Carvalho FMA, Pereira Filho RN, Ribeiro MAG, Albuquerque RLC Jr. Effects of different protocols of low-level laser therapy on collagen deposition in wound healing. Brazilian Dental Journal [Internet]. 2019 [cited 2020 Feb 29];30(4):317-24. Available from https:// www.scielo.br/pdf/bdj/v30n4/1806-4760-bdj-30-04-317.pdf

17. Barbosa LS, Parisi JR, Viana LC, Carneiro MB, Silva JRT, Silva ML, et al. The photobiomodulation (658, 830 and $904 \mathrm{~nm})$ on wound healing in histomorphometric analysis. Fisioterapia em Movimento [Internet]. 2020 [cited 2020 Nov 08];33:e003318. Available from: https://www. scielo.br/pdf/fm/v33/1980-5918-fm-33-e003318.pdf

18. de Carvalho PAG, Lessa RC, Carraro DM, Assis Pellizzon AC, Jaguar GC, Alves FA. Three photobiomodulation protocols in the prevention/ treatment of radiotherapy-induced oral mucositis. Photodiagnosis Photodyn Ther [Internet]. 2020 [cited 2020 Feb 29];31:101906. Available from: https://pesquisa.bvsalud.org/portal/resource/pt/mdl-32619713

19. Brasil. Conselho Federal de Enfermagem. Resolução n. 567 de 2018. Regulamenta a atuação do enfermeiro no cuidado aos pacientes com feridas [Internet]. Brasília; 2018 [cited 2021 Mar 30]. Available from: http://www.cofen.gov.br/resolucao-cofenno-567-2018_60340.html 